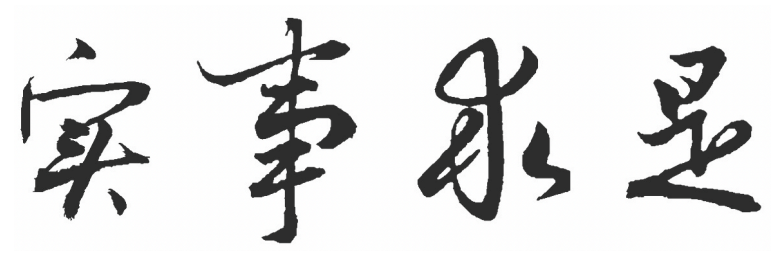

\title{
China's Technologies - The Hubris And The Reality
}

\begin{abstract}
Chang'e-5 landed successfully on the far side of the moon - that is indeed sensational news. China ranked 80th in the world in terms of GDP per capita - that is reality. The former is cause for hubris. The latter is a statistical fact. This article aims to make sense of some facts regarding China's technological progress but without the hyperbole. The article analyses the economies of China's most advanced provinces to determine the state of their economic and technological progress. In terms of technological progress China's top provinces today are where the United States was in 1981. In terms of economic development those provinces today are where Japan was in 1985.
\end{abstract}




\section{China's Technologies - The Hubris And The Reality}

Author: Kok Choy LOH

\section{The Hubris}

The litany of China's technological prowess goes something like this. Huawei is world leader in 5G technology. Chang'e-5 successfully landed on the far side of the moon. Jiuzhang's quantum computing is a hundred trillion times faster that the most powerful supercomputer of today.

In a sense these claims are factually true. And these are indeed admirable accomplishments. But the hubris over these achievements and the overblown conclusions drawn thereof often gets so exaggerated that these facts might as well be false. People who trumpet these isolated triumphs but fail to relate them to the whole picture fall into what logicians call a sampling fallacy. Each of these claims is factually correct. But they do not represent the true state of technology in China. When one travels across the whole of China the overall impression is not that of a technologically advanced country but that of one that is more appropriately described as developing. The hubris over China's crowning achievements do not quite jibe with the actual situation on the ground. Why is it so often that isolated micro realities paint a completely different picture from the macro reality? It is that age-old truism, that a part can never tell us all about the whole.

So it is hardly surprising that the question whether China is an advanced country is debated heatedly. But what I find surprising is that it is debated most outside of China. In my opinion it is a rather futile debate. The debate can have no definitive conclusion. Or should I say, the conclusion can be as varied as the number of ways one chooses to address the question.

This paper offers an answer from a macro point of view. It is by no means the only possible point of view. It is not even the only possible macro point of view. But it is one that is almost never mentioned in any of the debates. And never in the media. Yet variations of this same macro view are widely held by thinkers within China itself. And it is a view that is consistent with the mantra, to seek the truth through facts, that is sometimes attributed to the late leader Deng Xiaoping.

\section{The Facts}

Several years ago, there was this fascinating little book, The 1 Hour China Book, the cover of which is shown in Figure-1. The book was jointly authored by a senior executive at McKinsey \& Company and a private equity investor. The opening sentence in the book says it all. China is big. And that happens to be this article's first fact : China is big. [Towson \& Woetzel, 2013].

China is not only big. It is also economically quite heterogeneous. So, for example, Shanghai is not like Zhengzhou. And Zhengzhou is not like Lanzhou. When people think about China, most have only a mental image of a Chinese 1st tier city such as Shanghai, or Shenzhen, or Beijing. That is also true when people read about China. Even though some people might have visited China, they invariably ended up visiting one or two of only about half dozen cities. But there are more than one hundred cities in China with populations greater than one million. Few go inland to Zhengzhou, which has a population of ten million. And even fewer to Lanzhou, with a population of three million. But Shanghai, or Shenzhen, or Beijing are not really representative of the rest of China. Travelling from Shanghai to Zhengzhou and then to Lanzhou, one has the impression that one is travelling back in economic times. And the statistics corroborate that impression. Take for example the GDP per capita of provinces across the whole of China.

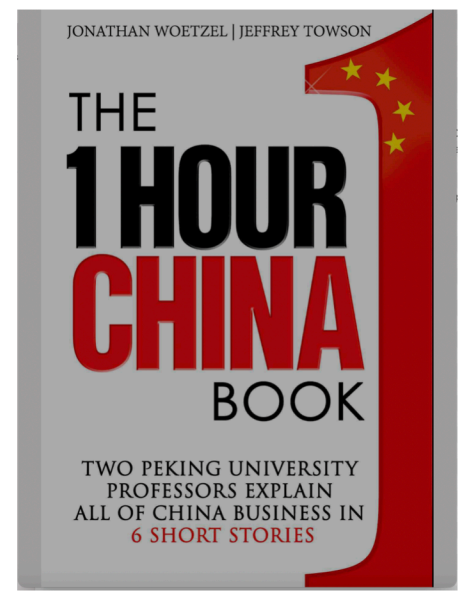

Figure 1. China is big

\section{GDP Per Capita}

GDP per capita is a metric that measures of the output of an economic region divided by the size of its population. The GDP per capita of an economic region is highly correlated with the technological capability of that region. It is therefore unsurprisingly GDP per capita often is used as a proxy to measure the technological sophistication of a region. So if one's impression is correct, one should discover that the GDP 


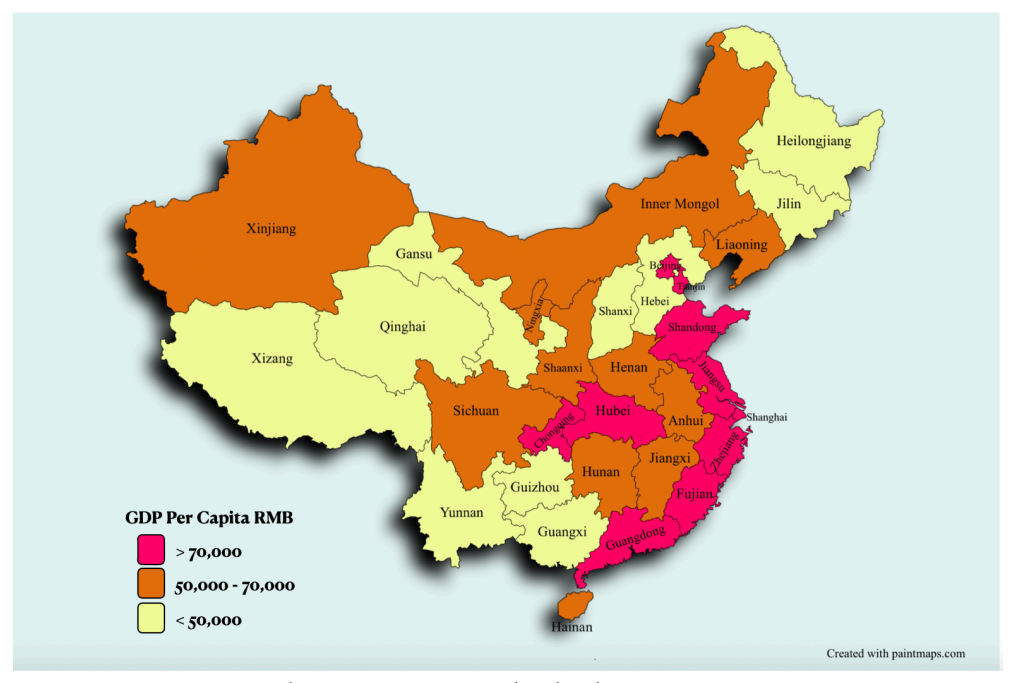

Figure 2. GDP per capita decreases as one travels inland per capita of Chinese cities that one visits decreases as one travels inland.

And indeed that is the case. Here are a few more facts. Shanghai has a GDP per capita ( statistics are for year 2019) of $157,000 \mathrm{RMB}$, whereas Zhengzhou is 100,000 RMB and Lanzhou is only 57,000 RMB.

What is true about cities is generally also true when comparing provinces of China, as is evident from Figure-2. The provinces where economic reform took root earliest are technologically more advanced and have the highest GDP per capita. These are also provinces that have greater contact and trade with the outside world. Ten Chinese provinces in

China have GDP per capita that exceed 70,000 RMB. [“China - Statistics \& Facts,” n.d.].

The top six provinces have a combined GDP per capita of 114,000 RMB. These are China's most advanced provinces. They are also exemplars of China's technological progress. So for our purpose we shall examine the state of technological sophistication of these six leading provinces and ask: Are these provinces as a whole indeed at the global frontier of technological advances?

Before we answer that question, first we ask, what is an appropriate metric for measuring technological sophistication? The usual proxy metric of technological sophistication is the GDP per capita. The combined GDP per capita of the six provinces is the combined output of these provinces divided by their combined populations.

\section{A Part Is Not The Whole}

But why use GDP per capita as the metric and not, say, the combined output of the leading companies or the leading industries? Specifically, why not use Huawei as the basis for measuring the technological advancement of these provinces? This question was indirectly answered in an earlier article, The Secret To Japan's Productivity. [Loh, 2018].

That article, The Secret To Japan's Productivity, included charts that revealed how different industries interacted. No industry was really a standalone. Each industry purchased from other industries and most sold to other industries. Japan's overall GDP per capita could only be understood if we understood the interactions between these industries. Figure- 3 reproduces three of the charts from that earlier article. In each of these charts, the gross value added (GVA) per worker of 108 industries was plotted against their capital intensity per worker. For our purposes the gross value added of an industry can be viewed as the sum of all incomes generated by that industry. And the sum of the gross value added of all 108 industries makes up the country's GDP. In other words GDP is just the GVA of the whole economy. Capital intensity is the amount of assets available to workers to perform productive work. In GDP lingo, what constitute capital are such assets as can be used to produce goods and services. Examples of capital in GDP lingo are factories, machineries, patents, investments in R\&D and so on. Cash and financial assets such as bonds or commercial papers or shares are not counted as capital in GDP. The Secret To Japan's Productivity demonstrated that capital intensity was a good proxy measure for technological intensity.

Starting with the left chart in Figure-3, each of the 108 industries is treated as a standalone industry. The 108 industries are arranged horizontally from the lowest GVA per worker to the highest. Each industry's GVA per worker is plotted as a dot with its capital intensity per worker represented by the height of the dot on the vertical axis. Notice that the result is just a jumble of dots. The chart can hardly be called a coherent picture of a close relationship between GVA per worker and capital intensity per worker.

Moving to the middle chart, instead of being shown as a standalone, each of the 108 industries is shown as the end-purchaser in a two-level value chain. In other words each industry is combined with the industries that are just one level upstream in its value chain. For example the GVA per worker of the retail industry is 
combined with an appropriate proportion of the GVA per worker of suppliers of merchandises, and with an appropriated proportion of the GVA of the real estate industry that provides retail premises, and so on. Notice that the relationship now becomes reasonably discernible.

And finally the right chart captures the relationship between GDP per capita and capital intensity per worker of the whole economy over the period 1950 to 2011. Notice that when the Japanese economy is viewed as a whole, the relationship between the economy's output (GDP) per worker and its capital intensity per worker is highly correlated.

The conclusion is quite clear. It is a mistake to pick a few isolated industries and draw conclusions about the whole economy. It is an even graver mistake to pick only one or two exemplary companies and imagine that those represent the state of play in the technology in China. Figure-3 shows clearly that it is not advisable to draw conclusions about the whole by viewing each part separately.
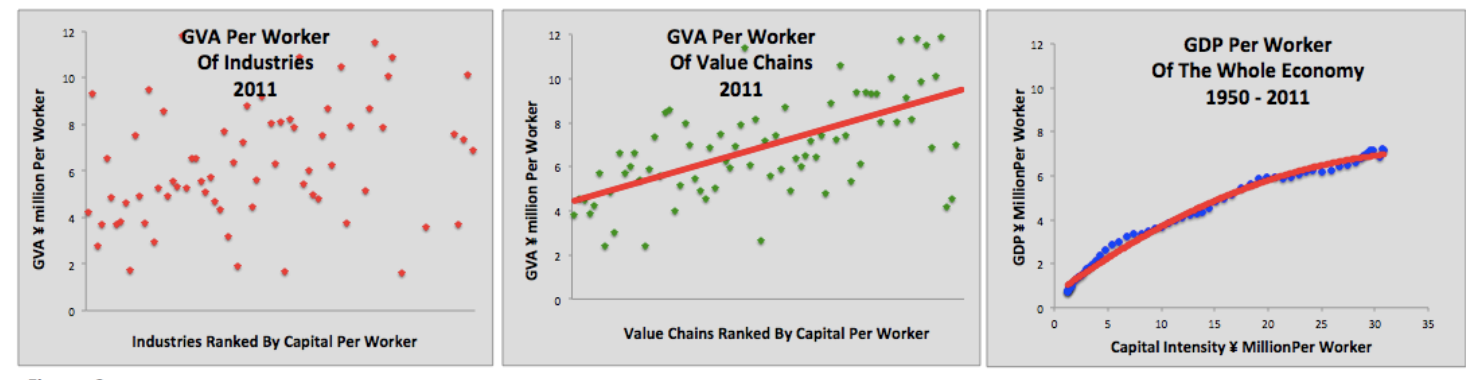

Figure 3. The relationship between GVA per worker and Capital per worker is barely discernable at the individual industry level. The relationship becomes discernable when each industry and its immediate input industries are combined. The relationship is clear when GVA per worker is plotted against Capital per worker for the entire economy

We have seen earlier that in the case of China there is great disparity in GDP per capita between the leading provinces and the rest of China. The question arises; is there also disparity in GVA per capita among industries within the leading provinces? Not only is there disparity among industries within the leading provinces, but also that that disparity is quite large. Take the case of Huawei. Its value added per worker is about. 1.23 million RMB per worker. [Huawei, 2018]. Compare that with the average GDP per capita, $114,000 \mathrm{RMB}$, of the six leading provinces Huawei's GVA per worker is approximately eleven times the average GDP per capita of the six leading provinces!

So Huawei is nothing like a typical company even among companies in China's most advanced provinces. Clearly Huawei, as a Chinese company, is an outlier. Huawei cannot be taken as a representation of the state of technological capability of the leading provinces.

If we are seeking a good indicator for the state of technological capability of China's leading provinces, it would be better to compare their combined average GDP per capita with that of the world's technologically most advanced country. So we shall compare the top six provinces with the United States

\section{Purchasing Power}

In order that we can compare the GDP per capita between these six provinces and the United States, we first must adopt a common unit of measurement for both economies. By convention, comparisons of GDP per capita are usually done using the US dollar as the unit of measurement. Now, the market exchange rate in 2019 was 6.90 RMB to a US dollar. However, it would be wrong to simply convert the GDP per capita in RMB to GDP per capita in US dollar using the then prevailing (market) exchange rate. Why would that be wrong?

To explain why, consider the price of a Big Mac. A Big Mac is prepared the same way and uses the same ingredients no matter whether it is bought in the United States or in France or in China. In 2019 a Big Mac would cost about US\$5.75 in the United States. All things being equal, the same Big Mac should cost about 39 RMB in China. But things in different countries are almost never entirely equal. According the Big Mac Index published by The Economist, in 2019 a Big Mac cost only 21 RMB in China. [The Economist, 2019]. So the Big Mac Index implies that one RMB in China buys $86 \%$ more that what the market exchange rate says it can buy. Or to put it colloquially, one RMB has the purchasing power of 1.86 RMB in China.

How is it that a Big Mac costs less in China than in the United States? Consider this. What costs go into the price of a Big Mac? Part of the price goes towards profits of course. And there are costs of ingredients. Of 
these, some ingredients, such as wheat that goes into making the buns, are traded globally. The price of wheat probably does not vary too much, at least not by $86 \%$, from one country to another. But beside ingredients such as wheat, a Big Mac has many other ingredients, including packaging materials, some of which might be obtained locally. And to sell its Big Mac, a McDonald's outlet has to incur other costs, such as rental and labour costs. These inputs into the sale of a Big Mac are not traded globally. No sensible business would want to incur operating costs greater than the gross value added (GVA) that the business can generate. Since, as we shall see later in this article, the average gross value added in China is lower than that in the United States, we can safely infer that rental and labour costs also are lower in China than they are in the United States. And if the costs of producing a Big Mac are lower the price can be correspondingly lower. That is why a Big Mac is cheaper in China, even though it is essentially the same Big Mac whether one buys it in China or in the United States.

Clearly then, using Big Mac as a currency exchange rate converter obfuscates the fact that there is no reason why things should cost the same around the world. Perhaps a haircut is an even better example to illustrate this. The cost of delivering a haircut comprises almost entirely of the costs of labour, rental and electricity. These are all local costs. Very little, if any, internationally traded ingredients goes into a haircut, perhaps just a small dab of hair gel applied at the end of the haircut. A haircut may cost US\$40 in a big city in the United States. ["Men's Haircut Prices", n.d.]. Now, US\$40 is about 276 RMB. How much does a decent haircut cost in a big city in China? I'm told it is about 100 RMB. So, taking this example where there is hardly any internationally tradable ingredient, the haircut implies that one RMB buys $176 \%$ more than what the market exchange rate says it can buy. One RMB has the purchasing power of $2.76 \mathrm{RMB}$ in China.

But a country's output is more than just things such as haircuts and Big Macs. A country's GDP also includes expenditures in acquiring manufacturing machineries, in constructing roads and building power stations. How much road does one RMB buy in China? Well, in the United States, it costs about US\$6.2 million per kilometre to construct an urban 4-lane road. [The American Road \& TransportationBuilders Association, n.d.]. In China the corresponding cost is about 26 million RMB per kilometre. So it seems that for every one million RMB China could build $64.5 \%$ more road than what the market exchange rate tells us.

So what exactly is the purchasing power of the RMB in China? If we consider the three examples of a Big Mac, a haircut, and a kilometre of urban road, the answer depends on which product or service we use as reference. That isn't very useful because if we are going to use the US dollar as a unit of measure, we need a consolidated purchasing power parity rate for the RMB in 2019. Fortunately, The World Bank compiles annually the weighted average purchasing power parity rates for different countries. In 2019, one RMB had the consolidated purchasing power of 1.63 RMB. [The World bank, n.d.].

That is to say, the purchasing power of the RMB in China is greater than the purchasing power of the US dollar in the United States. So to maintain parity in the comparison, we must adjust the GDP per capita of each of the six provinces by a factor of 1.63 .

\section{Comparing Economies}

When comparing economic performance between country, it is important to compare large economies with large economies and small economies with small economies. Large economies, especially ones with large populations, have the necessary scope to sustain a diverse economy which small economies do not. Small economies, especially those with small populations do not have the scope to sustain a diverse economy. This is because businesses require a certain size to enjoy the economy of scale needed to stay internationally competitive. Small countries necessarily have to focus on a few industries to optimise the deployment of its limited resources, especially of its limited labour force. Furthermore, large countries, with a large population have large domestic markets. So they have the capacity to absorb much of their own output. Small countries have small domestic markets. Yet, to stay competitive, small countries must produce large enough quantities of each product or service in order to enjoy the necessary economy of scale. Large quantities require access to a large market, which for small countries often means access to the global market. What companies produce large quantities and already have large global markets for their products? Multinational corporations of course. So small countries wishing to plug into the global market necessarily rely heavily on the "onshoring" of multinational corporations.

But having a large presence of multinational corporations distorts the GDP of small countries, as we shall see in the following story. It is a fascinating story of how the shenanigans of multinational corporations distort small countries' GDP. 
In 2015, Ireland's GDP jumped by a staggering 26\%. Ireland's economic performance in 2015 was so astounding that its 2015 GDP entered the Guinness World Records! [Guinness World Record, n.d.]. Since Ireland's population could not have grown by $26 \%$ in a year, we can safely guess that Ireland's GDP per capita would have grown by that same order of magnitude!

So here is the point. Before 2015 Ireland's GDP had been hovering around 5\% or 6\%. How then did Ireland's GDP manage to grow by an astounding $26 \%$ in one year? The story of how GDP grew $26 \%$ is good as any one could find to demonstrate how multinational corporations distort a small economy's GDP.

In its 2015 Budget, which was announced in October 2014, Ireland introduced a slew of changes to its corporate tax regime. [Government Of Ireland, 2014]. Among the changes was the introduction of the Knowledge Development Box. Income that could be traced to expenditures in intellectual property would be tax at only $6.25 \%$, which was half of the prevailing corporate tax rate. Together with an already low corporate tax, at $12.5 \%$, plus generous R\&D tax credits, the Knowledge Development Box provided great incentive for multinational corporations to domicile the ownership of their intellectual properties in Ireland.

Specifically how did multinational corporations take advantage of Ireland's 2015 tax schemes? Here we illustrate with a typical multinational corporation's Irish playbook. It transpired that in 2015 Ireland's rules for tax residency also changed to comply with new EU requirements. Before that, it was possible for multinational corporations to incorporate a subsidiary but declare the subsidiary as having no tax residency in any country. But that sort of corporate structure was no longer permissible in the European Union from 2015. So in 2015 the typical multinational corporation incorporated an Irish subsidiary, if it didn't already have one, and domiciled the subsidiary's tax residency in Ireland. That of course meant that the multinational corporation's Irish subsidiary now was potentially subject to Ireland's low $12.5 \%$ corporate tax rate. Later we shall discuss briefly why that didn't really mean that the subsidiary actually had to pay any tax at $12.5 \%$, but for now our interest here is how the GDP grew 26\%. And this was how.

All sales outside the United States was routed through and executed by this Irish subsidiary. Although the multinational corporation's products were contract manufactured in, say, China, the products made in China became the legal property of this Irish subsidiary. And although the products were shipped from China directly to countries around the worlds, the sales were recorded as sales by this Irish subsidiary. In other words, the products were shipped from China but were sold from Ireland, to the multinational corporation's own retailing subsidiaries as well as to third-party retailers around the world. The value that China captured in its GDP as contract manufacturer would probably amount to about $5 \%$ to $10 \%$ of the products' wholesale value. And the countries that supplied the components that went into to the product, and these were mostly developed economies such as Japan, Korea, the United States, and Singapore, captured a further 20\% to $30 \%$ of the value. That meant that the bulk of the value, between $60 \%$ and $75 \%$, became the income of the Irish subsidiary in Ireland. This value, $60 \%$ to $75 \%$, less perhaps a minuscule percentage for the cost of some Irish employees engaged in backroom paper shuffling, went directly as part of Ireland's GDP. Notice that neither the manufacturing nor the components that went into the products nor the finished products needed ever to touch Irish soil! Nonetheless the bulk of the GDP generated from the manufacture and and sale of this multinational corporation's products was captured in Ireland. China and other countries that contributed to the making of the products captured between $25 \%$ and $40 \%$ of the value in their GDP.

But that is not all there was to the story. That same multinational corporation also re-domiciled its intellectual properties in its Irish subsidiary. That move took advantage of the favourable tax reliefs. But how did that affect Ireland's GDP? Well, investments, including investments in intellectual properties, and R\&D expenditures, form part of a country's GDP. So that was how the Irish subsidiary's acquisition of (i.e. investment in) its parent corporation's intellectual properties further swelled Ireland's recorded GDP. And yes, the Irish subsidiary also assumed the bulk of the parent corporation's expenditures in R\&D, even though the actual research and development work continued to be carried out in the laboratories of the parent corporation.

That in a nutshell was how Ireland's GDP grew by $26 \%$. The 2015 episode moved Nobel laureate, Paul Krugman, to label the goings on in Ireland as leprechaun economics. [Krugman, 2017].

But why did the multinational corporation go through such lengths to place its intellectual properties and its global sales in an Irish subsidiary? It was done as part of tax management. Capital allowance (this is just accounting jargon for tax relief) for investments in intellectual properties, the amortisation of these intangible assets, tax credits against R\&D expenditures, as well as operating expenses, especially expenditures incurred 
as contract manufacturing fees, all these could be set off against the Irish subsidiary's global sales revenue. Therefore the residual taxable income, if any, would have been substantially reduced. And most of this residual taxable income, if any, would have been taxed at $6.25 \%$, through the application of the newly introduced Knowledge Development Box.

Such distortion on GDP could not happen but in a small country. Even though foreign multinational corporations have a large presence in China, their presence nonetheless is but a small fraction of the country's substantial economy.

\section{China's Most Advanced Provinces}

The long and short of it all is that when comparing economic performance between country, it is important to compare large economies with large economies and small economies with small economies. So for the purposes of comparing China's technological capabilities with that of the United States, we should combine the GDP per capita of a sufficiently large group of Chinese provinces such that the combined population would be comparable to the population of the United States.

Figure-4 tabulates the 2019 GDP per capita of the top six provinces in China. ["China - Statistics \& Facts," n.d.]. The weighted average GDP per capita of the top six provinces is $113,996 \mathrm{RMB}$. Converted to the then prevailing market exchange rate, the GDP per capita would be US\$16,525. [U.S. Bureau of Economic Analysis, 2021]. But we know that the purchasing power of the RMB is $63 \%$ higher than the market exchange rate. So, for comparison purposes, we use the GDP per capita, adjusted for purchasing power parity, which works out to be US\$26,995.

Notice that the top six provinces have a combined population of 338 million. That is within the ballpark number of the United States population. And both economies are large. So it makes sense to compare the combined GDP per capita of the top six provinces with the GDP per capita of the United States.

\begin{tabular}{|l|r|r|r|r|}
\hline \multirow{2}{*}{ Province } & \multicolumn{3}{|c|}{ GDP Per Capita } & \multicolumn{1}{c|}{$\begin{array}{c}\text { Population } \\
\text { million }\end{array}$} \\
\hline Beijing & 164,220 & 23,805 & 38,888 & 22 \\
Shanghai & 157,279 & 22,799 & 37,245 & 24 \\
Jiangsu & 123,607 & 17,918 & 29,271 & 81 \\
Zhejiang & 107,624 & 15,601 & 25,486 & 58 \\
Fujian & 107,139 & 15,531 & 25,372 & 40 \\
Guangdong & 94,172 & 13,651 & 22,300 & 114 \\
\hline Top 6 Provinces & 113,996 & 16,525 & 26,995 & 338 \\
\hline
\end{tabular}

Figure 4. GDP per capita of China's top 6 provinces at US\$26,995 is $40 \%$ of US GDP per capita. (Year 2019)

How do the top six provinces compare with the United States? Well, the GDP per capita of the United States in 2019 was about US\$65,426. In other words, the GDP per capita of the top provinces of China, at US $\$ 26,995$, was only about $41 \%$ that of the United States.

So we are confronted with a dichotomy between the hubris and the reality. On the one hand, we hear that China leads in $5 \mathrm{G}$ and that China achieved quantum computing speed that was far beyond what any super computer could attain. Yet on the other hand, using GDP per capita for comparison, the top six provinces in China is but $41 \%$ that of the United States. These are all factually based. So which in fact is the true representation of reality on the ground? How do we reconcile these two sets of conflicting facts?

The problem in part lies with the micro macro paradox. The mere three technologies, or for that matter even a dozen or more technologies, where China leads cannot be assumed to truly represent the whole state of technological capability in China. To get a better perspective of the whole economy (well, actually to get a better perspective of the economy of the top six provinces), we need a measure of the whole, not just selective parts of the whole. When it comes to comparing technological capability, GDP per capita is the better measure. But sadly most times the din of hubris drowns out the voice of statistical facts. 


\section{United States 1981}

What does it mean when we say that China's technological capability is $41 \%$ that of the United States? What mental image can we conjure up to help us visualise what $41 \%$ mean? There is another way to phrase this question. When was the GDP per capita of the United States approximately $41 \%$ the GDP per capita of present-day United States? Before we could sensibly answer that, we should note that US $\$ 1.00$ today is not likely to have the same purchasing power as US\$1.00 in the past. And here is why. As a country's GDP per capita rises, wages tend to rise. And as wages rise, consumption tends to rise. And as consumption rises, prices rise in tandem. That is just the consequence of supply trying to catch up with rising demand. And when prices rise one US dollar buys less. Furthermore, the US dollar today is no longer as strong vis a vis other currencies as it was in the past. And as the dollar weakens the price of imported goods becomes higher. Higher prices, i.e. inflation, erodes the purchasing power of the US dollar.

So in order to determine when in the past the GDP per capita was $41 \%$ of today's GDP per capita, we have to fix the purchasing power of the US dollar at a constant price level. We know already that the price level should not be based on just the price of a Big Mac, or a hair cut, or the cost to build a kilometre of road in the United States. It has to be based on a basket of prices that is representative of expenditures incurred in a typical year. Fortunately, the Federal Reserves publishes the GDP per capita based on a constant price. Currently that constant price is based on the 2012 US dollar. Well, it turns out that the GDP per capita of the United States in 1981 was approximately $41 \%$ of today's GDP per capita. [U.S. Bureau of Economic Analysis, 2021].

So one could imagine that, overall, the technological progress of the top provinces in China in 2019 was approximately where the United States was in 1981. Let's pause and reflect upon what we have found. We have taken some simple economic facts and arrived at the following conclusion. The most advanced provinces in China are about four decades behind the United States, in terms of progress in technology.

It is important to avoid drawing wrong conclusions from this statement. When we say that, overall, the technological progress of China is about four decades behind that of the United States we do not mean that China would catch up to the United States in forty years' time. While China is making technological progress, the United States is not standing still. Both the United States and China will be making technological advances over the next forty years. How their economy will compare in forty years time will depend on how fast each country progresses. However, intuitively we know that it is harder to develop new technologies than it is to adopt existing technologies. So the rate of technological advances achievable for a country such as the United States, which is at the frontier of new technologies, will likely be slower than the rate of advances for a catch-up country such as China. But exactly how that future will play out, when China will catch up, we shall leave that to crystal ball gazers.

And also it does not mean that the technologies deployed in China today would be exactly those of the 1980s. The world has moved on. In the early 1980s a mobile phone was the size of a brick, and as heavy. Today a Huawei smartphone can do a whole lot more that those brick-like mobile phones. Yet a Huawei smartphone weighs a mere $200 \mathrm{gm}$. The Huawei smartphone is a substantial enhancement to the original Motorola mobile phone. Nonetheless it is essentially an enhancement. It is not really a new technological invention. One could argue that the foundation for today's smartphones was laid in the early 1980s with the invention of the early brick-sized mobile phones.

Provided the we bear those qualifications in mind, that is, provided that we bear in mind that looking back four decades does not tell us anything about four decades looking ahead, and provided that we understand that the world has moved on since 1981, we can say that China's technological capability today relative to the United States is equivalent to the United State's capabilities in 1981 relative to the United States today.

\section{Japan 1985}

There is also another way to present the fact that China's GDP per capital is $41 \%$ that of the United States. We simply rephrase the question as follows. When was Japan in a similar position relative to the United States? When was Japan's technological capability $41 \%$ that of the United States? I know of no chart that gives us the answer. So here we shall make a stab at finding the likely answer. Let's take for consideration the year 1985. Well, in 1985, Japan’s GDP per capita was about $¥ 2.76$ million. ["Japan GDP - Gross Domestic Product," n.d.]. Since we are comparing Japan in 1985 with the United States in 1985, there is no need to take into account the two economies' inflations over the years. We can simply take the reported nominal GDP per capita of the two countries for the year 1985. In other words, we take 1985 as the base year. However, there is still the need to adjust for the difference between the market exchange rate and the 
actual purchasing power of the $¥$ in 1985 . Although the exchange rate in 1985 was $¥ 239$ to US\$1.00, the purchasing power of the ¥ within Japan was $¥ 194$ to US\$1.00. So, after juggling with some arithmetics, we find that Japan's GDP per capita in 1985, translated into US dollar, but adjusted for purchasing power, was US\$14,249.

In 1985 the GDP per capita in the United States was US\$33,442. That means that Japan's GDP per capita was about $43 \%$ that of the United State. In other words, Japan in 1985 was approximately where China is today relative the United States.

You might recall that around 1985 was also when Japan-bashing was at its most intense. The western media were full of alarmist warnings that Japan was going to eclipse the West. That was the time when books such as Japan As Number One went on the best-seller list. [Vogel, 1979]. That was also the time when Sony's Walkman reigned supreme in the consumer market. And Japanese car manufacturers were poised to overtake their American rivals. By 22nd September 1985, Japan had signed the Plaza Accord. Today, three and a half decades later, Japan is till struggling in the aftermath of that fateful accord. But that is another story for another occasion.

Today, looking back to those years, sans the hysteria, it is easy to see the flaws in those alarmist predictions. The alarmists portrayed the future as if it was going to be a repeat of the past. But the path into the future was not going to be like path taken in the past. For three decades before 1985, beginning in the early 1960 s, Japan was travelling on a well beaten technological path. That path had been hewn out and well trodden by the United States and other advanced western economies. As a follower of time-tested technologies, technological progress was relatively easy for Japan. What Japan needed to do was to excel in some already established technologies. And that Japan did.

So Japan soon dominated in car manufacturing. But car manufacturing was old hat. The United States had been at it for more than eight decades. It was time to move on. Nothing in economic affairs are ever static. Whilst Japan was catching up, the United States was not standing still. The best brains in the United States were no longer in Detroit. The brains were going to Silicon Valley, where the emerging technologies, such as genetics and information technology, were being hatched.

\section{Seeing The Truth Through Facts}

So coming back to the hubris over China's technological prowess, if we see the situation through the clear lens of economic facts, we see that in terms of economic development China today is still a developing country. In fact President Xi Jinping said as much when he mentioned that in terms of GDP per capita China ranked around 80th in the world. [Xi, 2014].

Even the most advanced provinces in China today are but where Japan was in 1985. Technologically China's top provinces relative to the United States are merely where the United States was in 1981. Serious thinkers who live by the mantra of seeing truth through facts, and I think Chinese leaders and economists in China are serious thinkers, are aware of the facts. The unwarranted hubris is but the work of some sensational media.

\section{$\underline{\text { References }}$}

Asian Infrastructure Investment Bank. (n.d.). Infrastructure Construction Costs In Asia. Retrieved from https://
www.aiib.org/en/news-events/asian-infrastructure-finance/construction.html

China - Statistics \& Facts. (n.d.). Retrieved from https://www.statista.com/topics/753/china/

Government Of Ireland. (2014). Financial Statement Of The Minister For Finance. Retrieved from http:// www.budget.gov.ie/budgets/2015/financialstatement.aspx

Guinness World Records. (n.d.). Highest Economic Growth (Country). Retrieved from https:// www.guinnessworldrecords.com/world-records/89717-highest-economic-growth-country

Huawei Investment \& Holding Co Ltd. (2018). 2018 Annual Report. Retrieved from https://www.huawei.com/en/ $\underline{\text { annual-report } / 2018}$

Japan GDP - Gross Domestic Product. (n.d.). Retrieve from https://countryeconomy.com/gdp/japan?year=1985

Krugman, P. (2017). Leprechaun Economics, With Numbers. Retrieved from https://krugman.blogs.nytimes.com/ 2017/11/09/leprechaun-economics-with-numbers/ 
Loh, K. (2018). The Secret To Japan's Productivity [Blog Post]. Retrieved from https://ftalphaville.ft.com/longroom/ content/71949

Men's Haircut Prices. (n.d.). Retrieved from https://www.menshairstylestoday.com/haircut-prices-barber-tip

The American Road \& TransportationBuilders Association. (n.d.). Frequently Asked Questions. Retrieved from

The Economist. (2020). The Big Mac Index. Retrieved from https://www.economist.com/news/2020/07/15/the-bigmac-index

The World Bank. (n.d.). PPP Conversion Factor, GDP. Retrieved from https://data.worldbank.org/indicator/ PA.NUS.PPP

Towson, J., \& Woetzel, J. (2013). The 1 Hour China Book: Two Peking University Professors Explain All Of China In 6 Short Stories. Towson Group LLC

U.S. Bureau of Economic Analysis. (2021). Real gross domestic product per capita [A939RX0Q048SBEA]. Retrieved from https://fred.stlouisfed.org/series/A939RX0Q048SBEA

Vogel, E. (1979). Japan As Number One: Lesson For America. Harvard University Press

Xi, J. (2014). Xi Jinping's Speech At College Of Europe. [Speech video recording]. Retrieved from https:// www.youtube.com/watch?v=07J3mVTUPyU 